\title{
Atypical form of amyotrophic lateral sclerosis
}

\author{
Shoichi Sasaki, Makoto Iwata
}

\begin{abstract}
Objective-To investigate patients with an unusual type of muscular atrophy confined to the upper limbs (proximally dominant) and the shoulder girdle, while sparing the face and the legs until the terminal stage.

Methods-Eight patients (six men and two women) were clinically examined. The age at onset ranged from 42 to 73 years, and the clinical course varied from 28 to 81 months. There was no family history of motor neuron disease in any of these patients. Necropsy was performed in two of them.
\end{abstract}

Results-All eight patients basically showed a similar distribution of muscular weakness and atrophy. Subluxation of the shoulder joints was found in all patients. Reflexes were absent in the upper limbs in all patients, but were almost normal in the face and legs in most patients. Pathological reflexes could be elicited in only one patient. Electromyography showed typical neurogenic changes in the limbs of all patients. Cervical MRI disclosed moderate spondylotic changes in seven patients. Antiganglioside antibodies were negative in six patients tested. Abnormal trinucleotide (CAG) repeat expansion of androgen receptor gene was not recognised in five patients examined. Bulbar involvement developed in three patients during the course of the disease. At necropsy, one patient showed degeneration of the pyramidal tracts and motor cortex including Betz cells as well as loss of spinal anterior horn cells and brainstem motor neurons, which is consistent with ALS; in another patient there was neuronal loss of anterior horn cells at the spinal cord accompanied by astrogliosis, whereas the motor cortex and brainstem motor nuclei were relatively well preserved. Intracytoplasmic inclusions such as Bunina bodies, skeinlike inclusions, and Lewy body-like inclusions were found in both patients.

Conclusion-These patients with their peculiar pattern of muscular atrophy seem to have ALS or a subtype of ALS. (7 Neurol Neurosurg Psychiatry 1999;66:581-585)

Keywords: amyotrophic lateral sclerosis, motor neuron disease, atypical muscular atrophy

Motor neuron disease is customarily divided into several subtypes on the basis of the particular combinations of symptoms and signs. ${ }^{1}$ Here we report eight unusual patients with motor neuron disease with an uncommon distribution of muscular atrophy, which was confined to the shoulder girdle and upper limbs predominantly the proximal region, while sparing the muscles of the face and legs for quite a long time or until the terminal stage.

\section{Methods and materials}

PATIENTS

The subjects were six men and two women aged from 47 to 76 years (mean 64.4 years), with an age at onset ranging from 42 to 73 years (mean 60.0 years) and a clinical course varying from 28 to 81 months (mean 55.5 months). Three patients had bulbar signs (cases 1, 2, and 7) and two of them died of pneumonia after a clinical course of 28 (case 1) and 56 months (case 2), respectively. The other two patients (cases 3 and 4) died of respiratory failure. Patient 3 was accidentally suffocated to death possibly due to sputa. Necropsy was performed in the two patients (cases 1 and 3) within 3 hours of death.

\section{NEUROPATHOLOGICAL STUDIES}

Tissue blocks were obtained from the brain and the spinal cord. Sections of the brain (including the motor cortex) and of the spinal cord at all levels were embedded in paraffin, cut into $6 \mu \mathrm{m}$ sections, and stained with conventional stains such as haematoxylin-eosin $(\mathrm{H}$ and E) stain, a modified Bielschowsky's silver impregnation stain, and Klüver-Barrera (cresyl violet) stain.

\section{Primary antibodies}

The following antibodies were used in the present study: a polyclonal glial fibrillary acidic protein (GFAP) antibody (Dako), a rabbit polyclonal antiserum $(200 \mathrm{kDa})$ to the 200 $\mathrm{kDa}$ protein of human neurofilament (a gift from Dr H Yamaguchi of the Department of Neurology, Gunma University) and a polyclonal antiubiquitin antibody (Sigma).

\section{Immunocytochemistry}

The primary antibodies were diluted with Tris-saline (50 mM Tris, $\mathrm{pH}$ 7.6, and $150 \mathrm{mM}$ $\mathrm{NaCl}$ ) as follows: polyclonal GFAP antibody (1:1000), polyclonal anti-200 kDa phosphorylated neurofilament antibody (1:1000), and polyclonal antiubiquitin antibody $(1: 10)$. Serial sections $(6 \mu \mathrm{m})$ of the paraffin embedded motor cortex and spinal cord were alternately subjected to $\mathrm{H}$ and $\mathrm{E}$ staining and immunostaining. Sections were deparaffinised and incubated with the diluted primary antibodies overnight at $4^{\circ} \mathrm{C}$. They were then visualised by the peroxidase antiperoxidase method (Dako) for GFAP, and by the avidin-biotin peroxidase complex procedure (Vectastain; Vector, Burlingame, CA, USA) for the other antibodies. 


\begin{tabular}{|c|c|c|c|c|c|c|c|c|}
\hline & $\begin{array}{c}\text { Patient } \\
1 \text { (necropsy) }\end{array}$ & $\begin{array}{c}\text { Patient } \\
2\end{array}$ & $\begin{array}{c}\text { Patient } \\
3 \text { (necropsy) }\end{array}$ & $\begin{array}{c}\text { Patient } \\
4\end{array}$ & $\begin{array}{c}\text { Patient } \\
5\end{array}$ & $\begin{array}{c}\text { Patient } \\
6\end{array}$ & $\begin{array}{c}\text { Patient } \\
7\end{array}$ & $\begin{array}{c}\text { Patient } \\
8\end{array}$ \\
\hline Sex & M & M & $\mathrm{F}$ & $M$ & $M$ & $\mathrm{~F}$ & $M$ & $M$ \\
\hline Age (y) & 72 & 76 & 76 & 48 & 48 & 67 & 67 & 64 \\
\hline Age at onset (y) & 69 & 71 & 73 & 42 & 45 & 61 & 61 & 58 \\
\hline $\begin{array}{l}\text { Clinical course } \\
\text { (months) }\end{array}$ & 28 (dead) & 56 (dead) & 32 (dead) & 71 (dead) & 41 (alive) & 81 (alive) & 69 (alive) & 66 (alive) \\
\hline $\begin{array}{l}\text { Initial site of } \\
\text { symptoms }\end{array}$ & R upper limb & L upper limb & R upper limb & R upper limb & R upper limb & R upper limb & L upper limb & R upper limb \\
\hline $\begin{array}{l}\text { Predominance of } \\
\text { muscle weakness } \\
\text { and atrophy }\end{array}$ & Proximal & Proximal & Proximal & Proximal & Proximal & Proximal & Proximal & Proximal \\
\hline $\mathrm{SCM}$ & Affected & Affected & Affected & Spared & Spared & Spared & Affected & Spared \\
\hline Bulbar signs & $\begin{array}{c}\stackrel{+}{\text { (13 months }} \\
\text { after onset) }\end{array}$ & $\begin{array}{c}\stackrel{+}{\text { (42 months }} \\
\text { after onset) }\end{array}$ & - & - & - & - & $\begin{array}{c}\stackrel{+}{\text { (12 months }} \\
\text { after onset) }\end{array}$ & - \\
\hline Fasciculation & All limbs & All limbs and trunk & - & All limbs & All limbs & All limbs & $\begin{array}{l}\text { Face, all limbs } \\
\text { and trunk }\end{array}$ & - \\
\hline Reflexes & $x^{+}$ & $x^{+}$ & $\mathrm{X}^{+}$ & $x^{+}$ & $x^{\#}$ & $x^{\prime \prime}$ & + & + \\
\hline $\begin{array}{l}\text { Complete loss } \\
\text { of reflexes }\end{array}$ & $\begin{array}{l}12 \text { months } \\
\text { after onset }\end{array}$ & $\begin{array}{l}17 \text { months } \\
\text { after onset }\end{array}$ & $\begin{array}{l}13 \text { months } \\
\text { after onset }\end{array}$ & $\begin{array}{l}48 \text { months } \\
\text { after onset }\end{array}$ & $\begin{array}{l}25 \text { months } \\
\text { after onset }\end{array}$ & $\begin{array}{l}37 \text { months } \\
\text { after onset }\end{array}$ & $\begin{array}{l}43 \text { months } \\
\text { after onset }\end{array}$ & $\begin{array}{l}60 \text { months } \\
\text { after onset }\end{array}$ \\
\hline EMG & $\begin{array}{l}\text { Neurogenic } \\
\text { changes in } \\
\text { all limbs }\end{array}$ & $\begin{array}{l}\text { Neurogenic } \\
\text { changes in } \\
\text { all limbs }\end{array}$ & $\begin{array}{l}\text { Neurogenic } \\
\text { changes in } \\
\text { all limbs }\end{array}$ & $\begin{array}{l}\text { Neurogenic } \\
\text { changes in } \\
\text { all limbs }\end{array}$ & $\begin{array}{l}\text { Neurogenic } \\
\text { changes in } \\
\text { all limbs }\end{array}$ & $\begin{array}{l}\text { Neurogenic } \\
\text { changes in } \\
\text { all limbs }\end{array}$ & $\begin{array}{l}\text { Neurogenic } \\
\text { changes in } \\
\text { all limbs }\end{array}$ & $\begin{array}{l}\text { Neurogenic } \\
\text { changes in } \\
\text { all limbs }\end{array}$ \\
\hline Cervical MRI & $\begin{array}{l}\text { Disc herniation } \\
\text { (C4-5), } \\
\text { Pincer } \\
\text { phenomenon } \\
\text { (C4-5) }\end{array}$ & $\begin{array}{l}\text { Narrow } \\
\text { spinal canal, } \\
\text { Disc protrusion } \\
\text { (C3-7), } \\
\text { pincer pheno- } \\
\text { menon (C4-5, C5 }\end{array}$ & $\begin{array}{l}\text { Disc } \\
\text { narrowing } \\
\text { (C3-7) } \\
\text { 5-6) }\end{array}$ & Normal & $\begin{array}{l}\text { Disc herniation } \\
\text { (C5-6), } \\
\text { hypertrophy of } \\
\text { ligament } \\
\text { flavum }\end{array}$ & $\begin{array}{l}\text { Disc herniation } \\
\text { (C4-5, C5-6), } \\
\text { Pincer pheno- } \\
\text { menon } \\
\text { (C4-5, C5-6) }\end{array}$ & $\begin{array}{l}\text { Slight } \\
\text { degenerative } \\
\text { change }\end{array}$ & $\begin{array}{l}\text { Narrow spinal } \\
\text { canal, } \\
\text { disc herniation } \\
\text { C5-6) }\end{array}$ \\
\hline Anti-GM1 antibody & NE & NE & - & - & - & - & - & - \\
\hline CAG repeat expansion & NE & NE & - & - & - & NE & - & - \\
\hline
\end{tabular}

Figure 1 Clinical profile of the patients. SCM= sternocleidmastoids; $N E=$ not examined; $+=$ positive; $-=$ negative.

\section{Electron microscopy}

The motor cortex and the anterior horns of the lumbosacral spinal cord were fixed in $2 \%$ glutaraldehyde with phosphate buffer $(\mathrm{pH}$ 7.40) at the time of necropsy. After fixation, these sections were cut into pieces about $1 \mathrm{~mm}$ thick, postfixed with $1 \%$ osmium tetroxide for 2 hours, dehydrated, and embedded in epoxy resin. Each block was then cut into semithin sections about $1 \mu \mathrm{m}$ thick and stained with toluidine blue. Appropriate regions were subsequently cut into ultrathin sections and stained with uranyl acetate and lead citrate for electron microscopy.

\section{Results}

CLINICAL FEATURES

The clinical details of the patients are shown in fig 1 . All eight patients basically showed a similar distribution of muscular weakness and atrophy, with atrophy being limited to the shoulder girdle (levator scapulae, pectoralis major, trapezius, deltoid, supraspinatus, infraspinatus, and interscapular muscles) and the upper limbs (fig 2). In addition, the cervical muscles including the sternocleidmastoids were af- fected in patients with a long course or in the terminal stage of the illness (patients 1, 2, 3, and 7). The proximal muscles of the upper limbs were more severely affected than the distal muscles in all patients, with proximal muscle power being graded at only $1 / 5 \sim 2 / 5$ and distal power at 3/5 4/5 in the advanced stage. The initial site of muscular weakness was the left upper limb in patients 2 and 7, and the right upper limb in the remaining 6 patients. Patients 1, 2 and 7 developed bulbar signs during the course of the disease $(13,42$, and 12 months after the onset of symptoms respectively). Subluxation of the shoulder joints was seen in all patients. Fasciculation was noted both in the upper limbs and legs in six patients and three of them also showed fasciculation in the tongue. Reflexes were absent in the upper limbs of all patients and were almost always normal in the face and legs. The reflexes in the upper limbs of eight patients were completely lost at $12,17,13,48,25,37,43$, and 60 months after the onset of symptoms respectively (average 31.9 months). Two patients showed slightly increased tendon reflex in the legs (cases 5 and 6). Pathological reflexes (positive Babinski's 

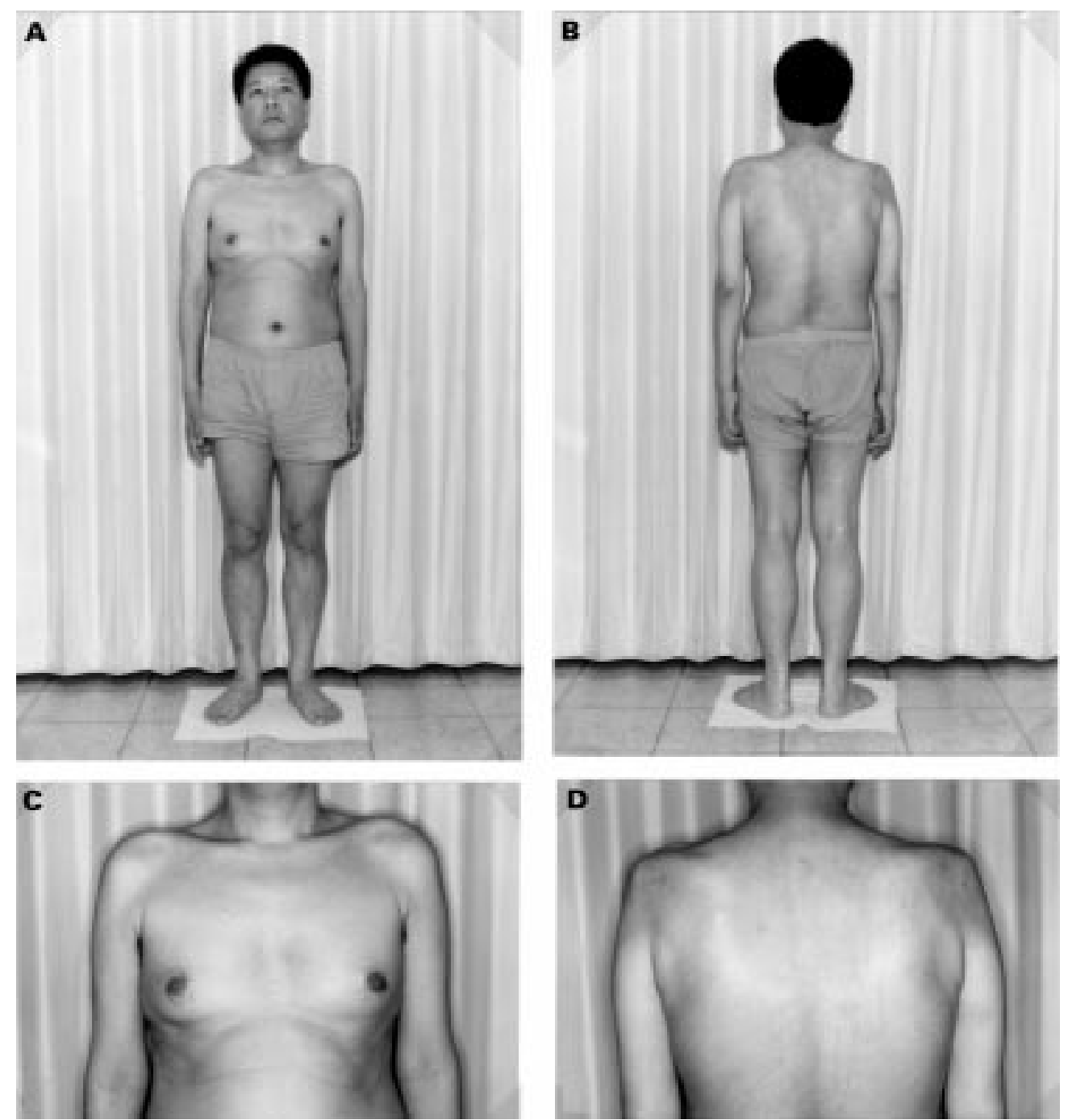

Figure 2 Patient 4 after 60 months of illness showing muscle atrophy being limited to the shoulder girdle and the upper limbs, while sparing the face and the legs. $(A)$ Frontal view; (B) back view; (C) high power view of $(A)$; and (D) high power view of (B).

sign) were consistently elicited in the legs of one patient (case 6). On EMG examination, reinnervation signs were demonstrated throughout the limbs in all patients, and denervation signs such as fibrillation and fasciculation were found in six patients (cases 1, 2, 4, 5, 6, and 7). Cervical MRI was performed in all patients, disclosing moderate spondylotic changes in all patients but one (patient 4) as shown in the table. Myelography was done in two patients (cases 5 and 8), showing median type disc herniation with compression of the spinal cord between $\mathrm{C} 5$ and C6 without narrowing of the nerve sleeves in patient 5, and defect of nerve sleeves at the left C5, C6, and C7 in patient 6. The creatine kinase (CK) concentration was slightly increased in all patients. Nerve conduction velocity (motor and sensory) was normal and there were no focal conduction blocks in all patients. Antibodies to GM1 and other glycolipids were negative in six patients (cases 3-8) who were examined. Patient 4 was ambulatory more than 5 years after the onset of symptoms and three patients (cases 6-8) are still ambulatory without difficulty in gait more than 5 years after the onset of muscle weakness and atrophy in the upper limbs. There was no family history of motor neuron disease, nor endocrinological impairment including gynaecomastia, in any of these patients. There was no abnormal expansion of trinucleotide (CAG) repeat of the androgen receptor gene on molecular biological study in five patients (cases $3,4,5,7$, and 8).

\section{NECROPSY FINDINGS}

\section{Patient 1}

Pathological examination showed marked loss of anterior horn cells at the cervical level accompanied by astrogliosis positively immunostained with anti-GFAP antibody. By contrast, anterior horn neurons persisted at the lumbosacral level, but most of the remaining neurons were degenerated. Bunina bodies were often seen in the remaining neurons. Immunohistochemically, ubiquitin positive skein-like inclusions and, less commonly, Lewy body-like inclusions were also found in anterior horn neurons. Many spheroids were seen, strongly immunostained by the polyclonal anti-200 kDa phosphorylated neurofilament antibody. 


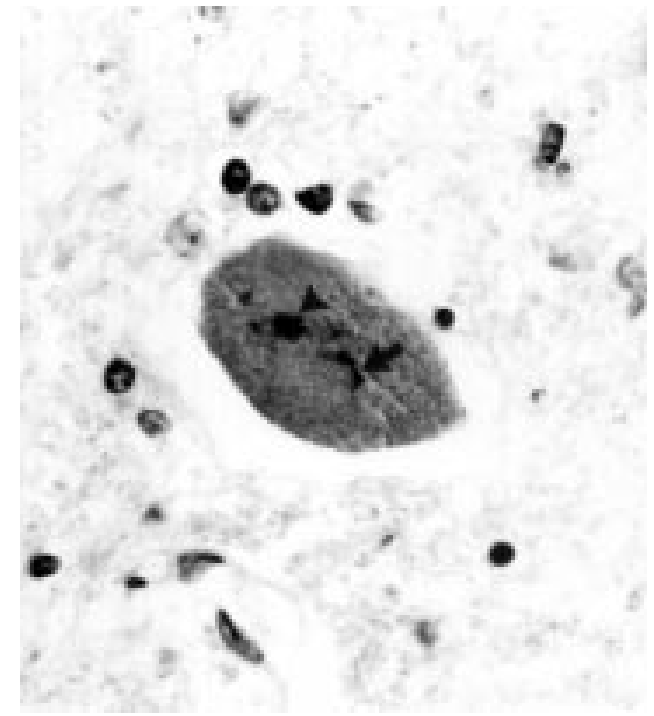

Figure 3 Ubiquitin positive skein-like inclusion (arrow) and Lewy body-like inclusion (arrow head) are seen in the perikaryon of an anterior horn neuron. Originally $\times 700$.

Moderate neuronal loss was noted in the hypoglossal nucleus, and the remaining neurons contained Bunina bodies. By contrast, the facial nerve nucleus was relatively well preserved, but some of the neurons contained Bunina bodies. The corticospinal tracts were degenerated at the level of the spinal cord. Electron microscopy showed Bunina bodies, skein-like inclusions, and Lewy body-like inclusions in anterior horn neurons and Betz cells.

\section{Patient 3}

Microscopical examination showed overall similarity with the pathological findings of patient 1. Anterior horn cells were markedly depleted at the cervical level accompanied by astrogliosis positively immunostained with anti-GFAP antibody. By contrast, anterior horn neurons at the lumbosacral level were relatively well preserved, but most of them were degenerated. Immunohistochemically, ubiquitin positive skein-like inclusions and Lewy body-like inclusions were seen in anterior horn neurons (fig 3). Many spheroids were found and immunostained by the antiphosphorylated neurofilament antibody. Betz cells and the lower motor neurons of the brainstem (trigeminal, facial, and hypoglossal motor nuclei) were relatively well preserved, and the pyramidal tracts were intact. Bunina bodies, skein-like inclusions, and Lewy body-like inclusions were found in the perikarya of anterior horn cells by electron microscopy, whereas no Betz cells had these inclusions.

\section{Discussion}

The clinical features such as the slowly progressive muscular weakness and atrophy, the presence of fasciculation throughout the limbs, and the diffuse neurogenic changes in the upper limbs and legs on EMG in our eight patients coincided with those of motor neuron disease. Weakness, atrophy, and fasciculations of the hands, arms, and shoulders may charac- terise ALS, sometimes as a dangling arm syndrome. ${ }^{2}$ Patients with ALS may lack upper motor neuron findings and they may have weakness largely limited to the upper limbs. However, in whatever part of the body muscular wasting begins, in most patients with ALS it spreads to the other parts of the body and sooner or later becomes generalised. More than $80 \%$ of patients with ALS with arm onset have ipsilateral or contralateral leg symptoms at 60 months after onset. ${ }^{3}$ On the other hand, about half of the patients with progressive spinal muscular atrophy (PSMA) have a symmetric wasting of intrinsic hand muscles, slowly advancing to the more proximal parts of the arms and less often still the proximal parts of the limbs are affected before the distal parts. Thus the pattern of muscular atrophy in our patients differed from that of typical ALS or PSMA in that severe muscle involvement was confined to the upper limbs, predominantly the proximal portion and shoulder girdle, sparing the face and the legs for a long time or until the terminal stage. Clinically, in particular, attention should be also called to the subluxation of the shoulder joints and the absence of the deep tendon reflexes in the upper limbs of these patients. Their immobile upper limbs were reminiscent of an orangutan's hands (orangutan sign or dead arm sign, personal communication from Professor emeritus Y Toyokura, The University of Tokyo).

With regard to duration of survival, $20 \%$ of patients with ALS live longer than 5 years after the onset of symptoms, ${ }^{4}$ whereas the 5 year survival is $72 \%$ in patients with the onset of PSMA before the age of 50 and $40 \%$ in patients with onset after $50 . .^{5}$ Thus our patients (cases 4 , 6,7 , and 8 , average age at onset 57.0 years) have a long clinical course for ALS or PSMA in that they are still ambulatory without difficulty in gait more than 5 years after the onset of symptoms.

The muscle atrophy confined to the shoulder and the proximal portion of the upper limbs (forme scapulohumérale) closely similar to that of our patients was described in motor neuron disease (PSMA) more than a century ago. ${ }^{67} \mathrm{Six}$ similar patients (five males and one female) with atypical muscular atrophy have also been reported in Japan in abstracts or photographs. $^{8-10}$ Furukawa $^{9}$ coined the term "suspended form" to describe this type of muscle atrophy because of its similarity to the distribution of segmental sensory impairment in syringomyelia. The age at onset in these six patients ranged from 48 to 68 years, and the clinical course was from 2 to 13 years. The authors who reported these patients considered that they were a subtype of PSMA. However, most of the patients also had cervical abnormalities such as cervical spondylosis or ossification of the posterior longitudinal ligament. Furthermore, no necropsy reports are available for these patients. Thus it remains unclear whether their progressive muscular atrophy was due to motor neuron disease, cervical spondylosis, or both diseases. Seven of our eight patients also had moderate cervical spine abnormalities, generally degenerative cervical 
spondylosis. It is conceivable that cervical abnormalities will cause the muscle atrophy limited to the shoulder and the proximal portion of the upper limbs, ${ }^{11}$ or influence the symptoms and signs of motor neuron disease in some way. Therefore, we cannot completely exclude the possibility of muscular atrophy being contributed to by a cervical spondylotic disease. However, the subsequent appearance of bulbar signs and the absence of disturbance of sensations such as numbness and hypaesthesia strongly suggest motor neuron disease rather than cervical spine abnormalities as the cause of the patients' muscle wasting.

This type of motor neuron disease must be also distinguished from multifocal motor neuropathy, ${ }^{12}{ }^{13}$ chronic segmental spinal muscular atrophy of upper extremities, ${ }^{14}{ }^{15}$ and an atypical form of a motor neuron disease lacking upper motor neuron symptoms such as $\mathrm{X}$ linked bulbospinal muscular atrophy (Kennedy-Alter-Sung syndrome). ${ }^{16}$ The symmetric and marked muscular atrophy (proximal preference of muscle atrophy of the arms), the absence of antiganglioside antibodies (antiGM1 antibody) and nerve conduction block, and the neurogenic changes on EMG in all our patients are inconsistent with multifocal motor neuropathy. ${ }^{12}{ }^{13}$ The age of onset, the distribution of muscle atrophy, and a clinical course with relentless progression in our patients distinctly differ from the segmental muscular atrophy of the upper extremities characterised by juvenile onset, unilateral or bilateral localisation of muscle atrophy to the intrinsic muscles of the hands and forearms, and a benign course. ${ }^{14}{ }^{15}$ Also the absence of trinucleotide (CAG) repeat expansion of the androgen receptor gene is inconsistent with bulbospinal muscular atrophy. ${ }^{16}$

If the El Escorial criteria for the diagnosis of $\mathrm{ALS}^{17}$ were applied to our patients, patient 6 might clinically fall into a slow evolving form of ALS, whereas the remaining seven patients would be categorised into the suspected form of ALS: PSPA in four patients (cases 3, 4, 5, and 8 ) and PSMA plus progressive bulbar palsy (PBP) in three patients (cases 1, 2, and 7 ). The necropsy findings of patients 1 and 3 are also compatible with those of MND: patient 1 showed involvement (degeneration) of the motor cortex including Betz cells and degeneration of the corticospinal tract as well as loss of spinal anterior horn cells and brainstem motor neurons, which is pathologically consistent with ALS despite the clinical diagnosis of the El Escorial suspected form of ALS; The neuropathological findings of pa- tient 3 are compatible with PSMA plus PBP (case 3). Thus it is important to remember that some cases of motor neuron disease may be characterised by unusual muscular atrophy confined to the upper limbs with the predominance of the proximal portion and the shoulder girdle with a variable clinical course that may progress to bulbar involvement. The patients with such a peculiar pattern of muscular atrophy should perhaps be categorised as ALS or a subtype of ALS.

This work was supported in part by a grant in aid for General Scientific Research (C) from the Japanese Ministry of Education, Science, and Culture. We thank Drs S Igarashi and M Onodera (Department of Neurology, Brain Research Institute, Niigata University) for performing the DNA diagnostic test of CAG repeat expansion of androgen receptor gene and Dr S Kusunoki (Department of Neurology, Institute of Brain Dr S Kusunoki (Department of Neurology, Institute of Brain antiganglioside antibodies.

1 Rowland LP. Diverse forms of motor neuron disease. In: Rowland LP, ed. Human motor neuron disease. Advances in neurology. Vol 36. New York: Raven Press, 1982:1-13.

2 Adams RD, Victor M. Principles of neurology. 4th ed. New York: McGraw Hill, 1989:1097.

3 Brooks BR, Shodis KA, Lewis DH, et al. Natural history of amyotrophic lateral sclerosis. Quantification of symptoms, signs, strength, and function. In: Serratrice J, Munsat TL, eds. Pathogenesis and therapy of amyotrophic lateral sclerosis. Advances in neurology. Vol 68. Philadelphia: LippincottRaven, 1995:163-84

4 Mulder DW. Clinical limits of amyotrophic lateral sclerosis. In: Rowland LP ed. Human motor neuron diseases. Advances in neurology. Vol 36. New York: Raven Press, 1982:15-22.

5 Chio A, Brignolio F, Leone $M$, et al. A survival analysis of 155 cases of progressive muscular atrophy. Acta Neurol 155 cases of progressive
Scand $1985 ; 72: 407-13$.

6 Pierret, T. Note sur deux cas d'atrophie musculaire progresPive. 2éme série, March-April. Arch Physiol Norm Pathol
siver (Paris) $1875 ; 2: 236-52$.

7 Vulpian A. Cours de pathologie expérimentale. Maladies du système nerveux (Moëlle épinière). Leçons professées à la Faculté de Médecine. (23 ème Lecon; Affections systématiques de la substance grise de la moëlle épinière (Suite). Atrophie musculaire progressive myélopathique.) Vol 2. Paris: Octave Doin, 1886:412-91

8 Kachi T, Sobue I, Teramoto J. Spinal progressive muscular atrophy with unique clinical type [abstract]. Rinshoshinkeigaku 1980;20:1132.

9 Furukawa T. Muscular atrophy of forme de suspension. Neurol Med (Tokyo) 1980;13:574-5.

10 Tsuchiyama M, Kodama N, Tachibana H, et al. Muscular atrophy of "forme de suspension". Neurol Med (Tokyo) 1992;37:195-6.

11 Keegan JJ. The cause of dissociated motor loss in the upper extremity with cervical spondylosis: a case report. 7 Neurosurg 1965;23:528-36.

12 Lewis RA, Sumner AJ, Brown MJ, et al. Multifocal demyelinating neuropathy with persistent conduction block. Neurology 1982;32:958-64.

13 Roth G, Rohr J, Magistris MR, et al. Motor neuropathy with proximal multifocal persistent conduction block, fasciculations and myokymia. Eur Neurol 1986;25:416-23.

4 Hirayama K, Toyokura Y, Tsubaki T. Juvenile muscular atrophy of unilateral upper extremity: a new clinical entity. fapanese fournal of Psychiatry and Neurology 1959;61:21907.

15 Tandan R, Sharma KR, Bradley WG, et al. Chronic segmental spinal muscular atrophy of upper extremities in identical twins. Neurology 1990;40:236-9.

16 La Spada AR, Wilson EM, Lubahn DB, et al. Androgen receptor gene mutations in X-linked spinal and bulbar receptor gene mutations in X-linked sp
muscular atrophy. Nature 1991;352:77-9.

17 Brooks BR. World Federation of Neurology Sub Committee on Neuromuscular Diseases. El Escorial criteria for the diagnosis of amyotrophic lateral sclerosis. 7 Neurol $S_{c i}$ 1994;124(suppl): $96-108$. 